\title{
Relationship of Thyroid Stimulating Hormone with Coronary Artery Disease in Patients Undergoing Diagnostic Coronary Angiography
}

\author{
Zahra H. Abdulbaki \\ Department of Clinical Pharmacy \\ College of Pharmacy \\ University of Mosul
}

\author{
Hazim A. Mohammed \\ Department of Biochemistry \\ College of Medicine \\ University of Mosul
}

(Received 22/5/2012;Accepted 18/7/2012)

\begin{abstract}
In this cross-sectional study, a sample of 150 patients ( 88 men and 62 women) of age $53.28 \pm 9.6$ years who underwent diagnostic coronary angiography. Blood was used for the measurement of serum thyroid stimulating hormone (TSH), free thyroxine (FT4) concentration and serum lipid profile total cholesterol (TC), triglyceride (TG), low density lipoprotein-cholesterol (LDL-C) and high density lipoprotein- cholesterol (HDL-C). Mean serum concentration of lipid profile across different groups of TSH level, $(<0.38,0.38-4.31$ and $>4.31 \mathrm{mIU} / \mathrm{L}$ ) was calculated in order to study the association of TSH with prevalence of CAD. The severity of CAD was scored as score $(0)$ for those with smooth normal coronary artery while score 1,2 and 3 for those with single, double and triple-coronary artery of $\geq 50 \%$ stenosis, respectively. Score 4 indicated left main coronary artery with $\geq$ $50 \%$ stenosis. The mean serum TSH was significantly higher in women than men $(\mathrm{p}=0.005)$. There was no significant difference between mean serum TSH level across different score groups $(\mathrm{p}=0.7)$. High level of TSH was observed in the multi-vessel disease, (score 2, 3 and $4 \mathrm{p}=0.03$ ). It was found that serum TC, LDL-C and TG increased while HDL-C decreased with increased TSH level.

This study suggested that the high level of TSH is associated with multi-vessel disease and slight elevation of TSH also leads to changes in lipid profile that raise the risks of cardiovascular disorders.
\end{abstract}

Keywords: Thyroid stimulating hormone, subclinical hypothyroidism, overt hypothyroidism, coronary artery disease, coronary angiography.

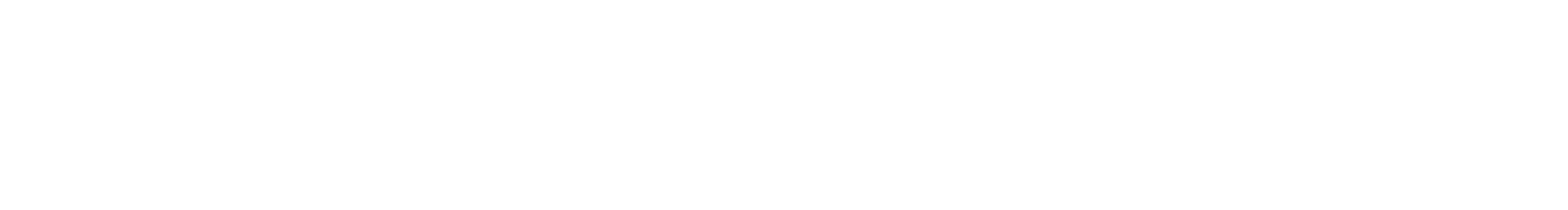

\section{الملغص}

تصميم الدرلسة كان درلسة المطع العرضي في عينة من 150 مريضاً (88 نكراً و 62 أنث بأعمار

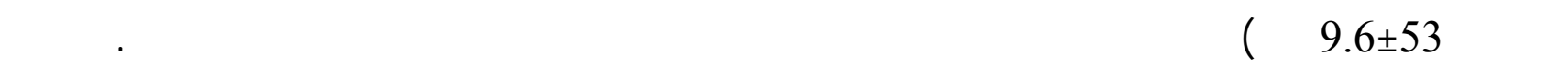


عينت الدم ولجريت عليها الفحوصك المصلية لترلكيز الهرمون المحفز للغدة الدرقية، هرمون الثيروكسن

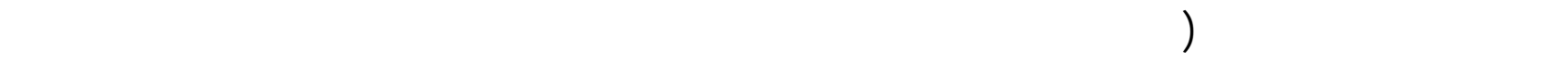

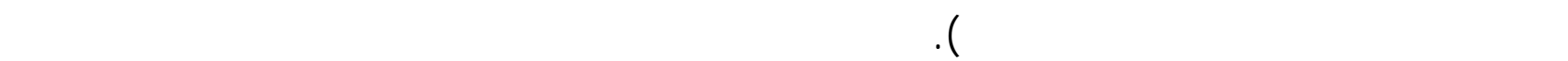

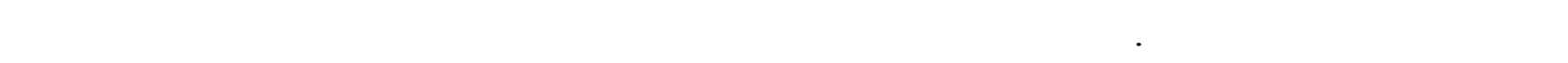
شدة الإصابة بدرجة (0) للأشخاص الذنششرايينهم التلجيةسليمة وشدة الإصابة بدرجة (1,2,3) للأشخاص

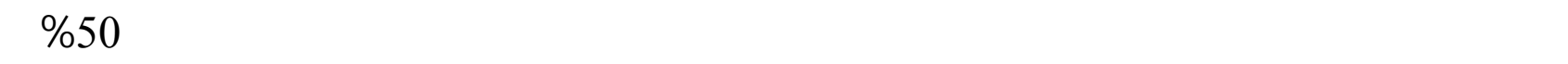

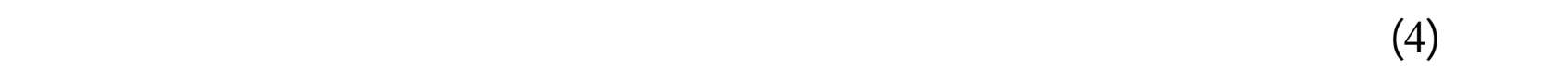

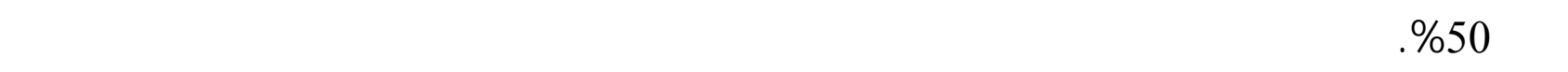
النساء (P=0.005). لم تبدي النتائج وجود علاقة بين مستوى الهرمون المحفز لإفراز الغة الدرقية ووجود

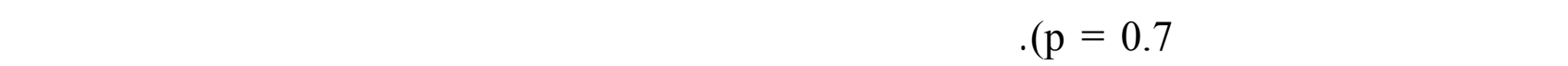

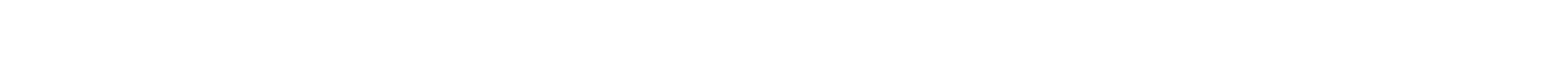

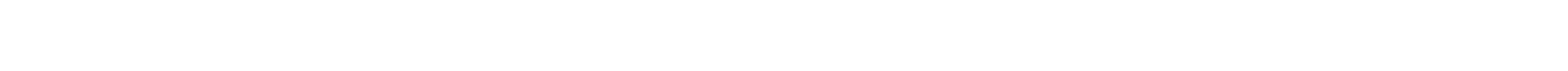

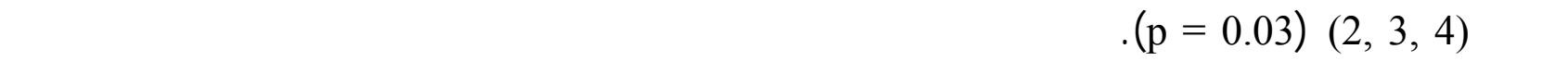

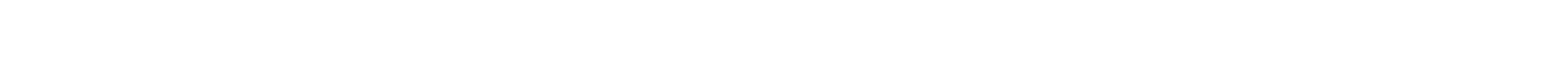
البروتين الدهن للكولسترول العالي الكثافة مع زياة الهرمون. اقترحت هذه الدرلسة وجود علاقة بين

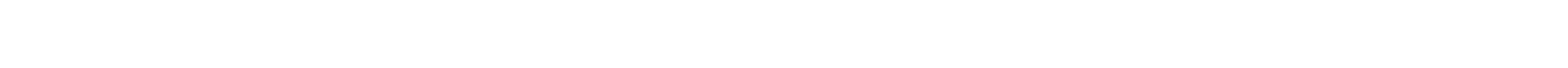

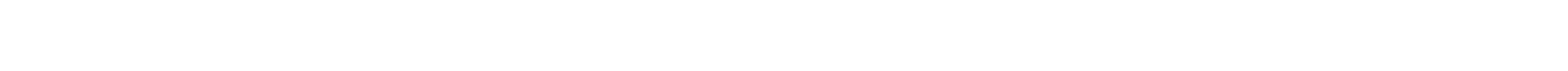
قصص التروية الموية.

الكامل الدالة: الهرمون المحفز لإفراز الغة الدرقية، قص إفراز الدرق الواضح، قص إفراز الدرقشبه اللسريري، أمراض اللثرايين التلجية، قططرة للثرايين التلجية.

\section{INTRODUCTION}

Overt hypothyroidism $(\mathrm{OH})$ is associated with the abnormality of blood lipids and the increased risk of cardiovascular disease (CVD) (Becker et al., 1985). Subclinical hypothyroidism $(\mathrm{SCH})$ is a symptomatic state characterized by normal serum concentrations of freeT4 (FT4) and elevated serum concentrations of thyroid stimulating hormone (TSH). Moreover, it is associated with an increase risk of CVD (Tieche et al., 1981). The SCH is increased with age and it is higher in women than men (Surks et al., 2004).

However, most of cardiovascular events occur in subjects with normal thyroid functions (Bakker et al., 2001). Thus, the question whether an association of TSH with CVD also exists in the euthyroid state or not is important. In one study addressed this question showed a significantly higher TSH level in patients with coronary heart disease (CHD) compared 
with healthy controls matched for age, sex and body mass index (BMI) (Miura et al., 1996). Interestingly, this difference could not be explained by a higher incidence of SCH.

The association of $\mathrm{OH}$ and $\mathrm{SCH}$ with hyperlipidemia might be extended to the normal range of thyroid functions (Asvold et al., 2007). Some studies have shown that serum lipids might also be altered within normal ranges of thyroid functions that is considered clinically normal (Iqbal et al., 2006). Certain authors reported that serum total cholesterol (TC), low density lipoprotein-cholesterol (LDL-C) and triglyceride (TG) increased with the increase of the TSH level while high density lipoprotein-cholesterol (HDL-C) decreased with the increase of the TSH level (Pallas et al., 1991).

In this study, we determine whether there is a relationship between the variation of $\mathrm{TSH}$ within the reference range and the presence and severity of CAD. Moreover, to find whether there is an association of serum lipid concentration with the level TSH.

\section{MATERIALS AND METHODS}

A cross- sectional study was carried out in IBN-SINA Teaching Hospital in Mosul city during the peroid from $1^{\text {st }}$ of November 2011 to the $1^{\text {st }}$ of March 2012. The protocol of this study was approved by the regional research Committees at the College of Medicine and Mosul Health Administration.

One hundred and fifty patients clinically referred for the unit of coronary angiography to evaluate their chest pain, (88 males and 62 females) aged (30 - 78) years with mean \pm standard deviation (SD) of $(53.3 \pm 9.6)$ years. Patients with a history of thyroid diseases, chronic debilitating illnesses and those receiving medications that interfere with thyroid functions and serum lipid estimation were excluded.

After obtaining informed consent, data of age, sex, coronary risk factors (hypertension, hyperlipidemia, diabetes mellitus (DM), smoking habit and obesity), Systolic (SBP) and diastolic (DBP) blood pressure were measured with standard mercury sphygmomanometer from the arm after the patient seated for five minutes prior to the measurement. Body mass index (BMI) was computed as weight divided by squared meter. Obesity was defined as BMI of $\geq 30 \mathrm{Kg} / \mathrm{m}^{2}$ (Chan et al., 2003).

After 12 hrs of fasting period, coronary angiography was performed by percutaneous transfemoral technique according to the Judkins method (Judkins, 1976). The results of coronary angiography are classified according to the scoring system (Ringqvist et al., 1983).

The severity of CAD was scored as (0) for smooth normal coronary arteries, score $(1,2$ and 3 ) for those with single, double, triple- coronary artery of $\geq 50 \%$ stenosis, respectively. Score (4) designated left main disease was applied on left main coronary artery of $\geq 50 \%$ stenosis.

Biochemical parameters including TC, TG, HDL-C were measured enzymatically using kits supplied from (Biolabo, France). Serum LDL-C was calculated by Friedewald equation (Friedewald et al., 1972; Burtis et al., 2006) as follows:

LDL-C = TC- (HDL-C) - TG $/ 2.22(\mathrm{mmol} / \mathrm{l})$.

Atherogenic Index(AI) is calculated by the following equation:

$\mathrm{AI}=\mathrm{TC} / \mathrm{HDL}-\mathrm{C}$ (Bishop et al., 2005).

Serum TSH and FT4 was measured by Automated enzyme immunoassay system, AIA-360 TOSOH analyzer (Tosoh, Japan ) 
Patients were classified into three groups according to their TSH levels $(<0.38,0.38$ 4.31 and $>4.31 \mathrm{mIU} / \mathrm{L})$, then a score of CAD was assessed for each group.

The statistical analysis was performed as follows:

- Data were expressed as mean \pm (SD).

- Paired and unpaired Student's $t$-test for the differences between groups for continuous variables.

- Analysis of one way variation (ANOVA) test was applied when more than two groups were compared.

- Chi-square $\left(\mathrm{X}^{2}\right)$ was used to compare the proportions in qualitative variables and to analyze the relations between TSH levels and score of angiography.

The results were considered statistically significant at $\mathrm{p} \leq 0.05$.

\section{RESULTS}

The severity of CAD was scored as $0,1,2,3$ and 4 in 51, 45, 23, 27 and 4 patients, respectively (Fig.1).

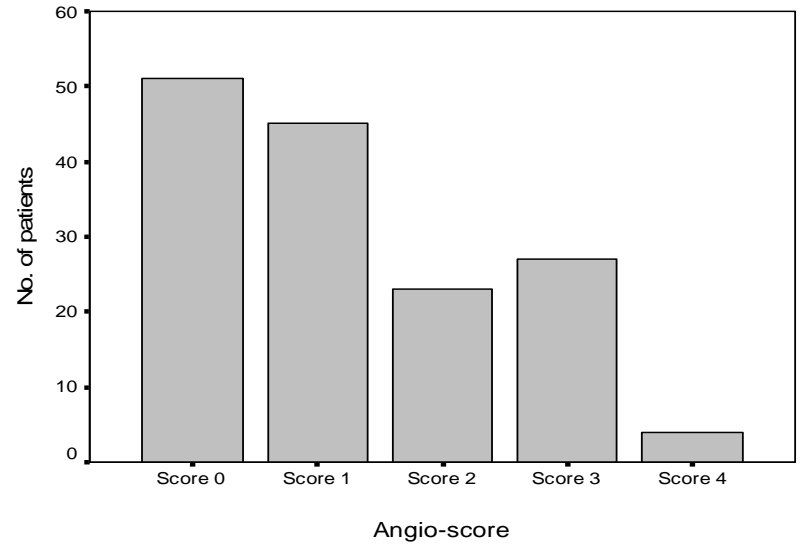

Fig.1: Severity of CAD in the overall patients

Table (1) shows patients characteristics according to angiography scores regarding the history of the underlying disease and smoking. Among the conventional risk factors for CAD, patient's age $(p=0.007)$, male $(p=0.001)$, hypertension $(p=0.05)$, diabetes mellitus $(\mathrm{p}=0.02)$, hyperlipidemia $(\mathrm{p}=0.05)$ and smoking $(\mathrm{p}=0.001)$.

\section{Table 1: Characteristics of patients according to angiography scores}

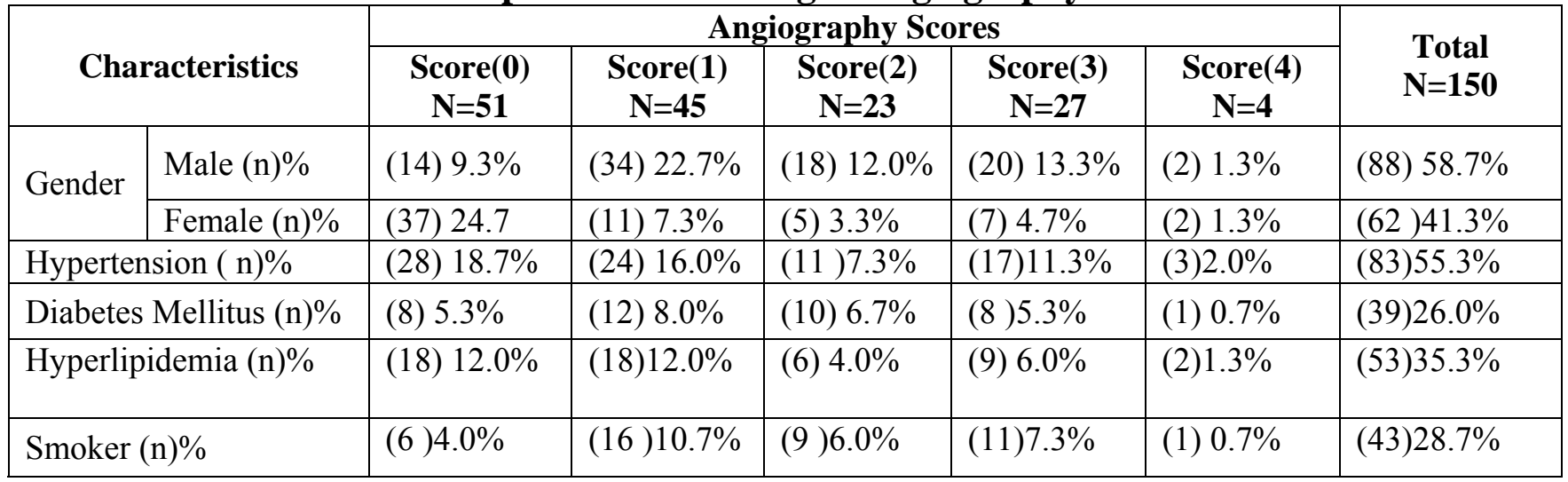


The data are expressed as number (n) and percentage (\%). The differences in frequencies were performed by $\chi^{2}$ test.

Table (2) shows patients characteristics according to the angiography score regarding age, SBP, DBP, BMI, TSH, FT4, TC, HDL-C, LDL-C, TG and AI. The severity of CAD increased significantly with age, BMI increases significantly with the increase of the angiography score. Also TC, LDL-C, TG and AI show a significant increase across angiography score, while HDL-C significantly decrease. Although TSH insignificantly increased with the severity of CAD as in (score 3 and 4).

Moreover, there was no significant difference regarding the mean TSH level across different score groups $(p=0.7)$. Free $T 4$ shows non significant decrease across the angiography score. The mean SBP and DBP show non significant difference among angiography score.

Table 2: Characteristics of patients according to angiography scores.

\begin{tabular}{|c|c|c|c|c|c|c|}
\hline \multirow[b]{2}{*}{ Characteristics } & \multicolumn{5}{|c|}{ Angiography Scores } & \multirow[b]{2}{*}{$\begin{array}{c}\text { P- } \\
\text { value }\end{array}$} \\
\hline & $\begin{array}{c}\text { Score (0) } \\
N=51\end{array}$ & $\begin{array}{c}\text { Score (1) } \\
\mathrm{N}=45\end{array}$ & $\begin{array}{c}\text { Score (2) } \\
\mathrm{N}=23\end{array}$ & $\begin{array}{c}\text { Score (3) } \\
\mathbf{N}=27 \\
\end{array}$ & $\begin{array}{c}\text { Score (4) } \\
\mathrm{N}=4\end{array}$ & \\
\hline Age (Years) & $\begin{array}{c}52.01 \pm 9.68 \\
(30.00-76.00) \\
\end{array}$ & $\begin{array}{c}51.77 \pm 8.43 \\
(33.00-67.00) \\
\end{array}$ & $\begin{array}{r}53.30 \pm 10.24 \\
(34.00-78.00) \\
\end{array}$ & $\begin{array}{r}55.92 \pm 8.68 \\
(36.00-72.00) \\
\end{array}$ & $\begin{array}{c}68.25 \pm 11.84 \\
(51.00-76.00)\end{array}$ & 0.007 \\
\hline $\mathrm{SBP}(\mathrm{mm} \mathrm{Hg})$ & $\begin{array}{l}135.68 \pm 20.64 \\
(100.00-185.00)\end{array}$ & $\begin{array}{c}126.66 \pm 19.94 \\
(80.00-170.00)\end{array}$ & $\begin{array}{r}135.86 \pm 18.06 \\
(110.00-185.00)\end{array}$ & $\begin{array}{c}138.70 \pm 21.68 \\
(100.00-180.00)\end{array}$ & $\begin{array}{l}135.00 \pm 26.45 \\
(100.00-160.00)\end{array}$ & N.S. \\
\hline $\mathrm{DBP}(\mathrm{mmHg})$ & $\begin{array}{c}79.50 \pm 11.36 \\
(60.00-120.00)\end{array}$ & $\begin{array}{c}78.66 \pm 19.14 \\
(50.00-185.00)\end{array}$ & $\begin{array}{c}79.13 \pm 9.49 \\
(70.00-100.00)\end{array}$ & $\begin{array}{c}81.85 \pm 12.33 \\
(60.00-110.00)\end{array}$ & $\begin{array}{c}73.75 \pm 7.50 \\
(65.00-80.00)\end{array}$ & N.S. \\
\hline BMI $\left(\mathrm{Kg} / \mathrm{m}^{2}\right)$ & $\begin{array}{c}31.53 \pm 6.87 \\
(20.43-55.55)\end{array}$ & $\begin{array}{c}29.85 \pm 5.43 \\
(22.49-42.65)\end{array}$ & $\begin{array}{c}27.87 \pm 4.38 \\
(19.75-37.77) \\
\end{array}$ & $\begin{array}{c}28.86 \pm 3.37 \\
(23.66-34.89)\end{array}$ & $\begin{array}{c}28.22 \pm 3.16 \\
(23.88-31.39) \\
\end{array}$ & 0.05 \\
\hline TSH (mIU/L) & $\begin{array}{c}2.09 \pm 1.93 \\
(0.30-13.41) \\
\end{array}$ & $\begin{array}{c}1.79 \pm 1.09 \\
(0.26-5.47) \\
\end{array}$ & $\begin{array}{l}1.72 \pm 0.97 \\
(0.42-4.55) \\
\end{array}$ & $\begin{array}{c}1.89 \pm 1.14 \\
(0.79-5.25) \\
\end{array}$ & $\begin{array}{l}1.38 \pm 0.40 \\
(1.02-1.74) \\
\end{array}$ & N.S. \\
\hline FT4 (ng/dl) & $\begin{array}{l}1.44 \pm 0.30 \\
(0.69-2.15) \\
\end{array}$ & $\begin{array}{c}1.40 \pm 0.28 \\
(0.89-2.01) \\
\end{array}$ & $\begin{array}{c}1.47 \pm 0.32 \\
(1.01-2.06) \\
\end{array}$ & $\begin{array}{c}1.40 \pm 0.31 \\
(0.75-2.17) \\
\end{array}$ & $\begin{array}{l}1.23 \pm 0.23 \\
(0.95-1.44) \\
\end{array}$ & N.S \\
\hline $\mathrm{TC}(\mathrm{mmol} / \mathrm{L})$ & $\begin{array}{l}3.97 \pm 1.07 \\
(2.44-6.19)\end{array}$ & $\begin{array}{l}4.19 \pm 1.24 \\
(1.84-7.31)\end{array}$ & $\begin{array}{l}4.58 \pm 1.11 \\
(2.18-8.06) \\
\end{array}$ & $\begin{array}{l}4.53 \pm 1.29 \\
(2.76-7.04) \\
\end{array}$ & $\begin{array}{l}4.33 \pm 1.02 \\
(3.11-5.49)\end{array}$ & 0.02 \\
\hline $\begin{array}{l}\mathrm{HDL}-\mathrm{C} \\
(\mathrm{mmol} / \mathrm{L})\end{array}$ & $\begin{array}{c}1.09 \pm 0.32 \\
(0.56-2.20) \\
\end{array}$ & $\begin{array}{c}0.94 \pm 0.20 \\
(0.31-1.37) \\
\end{array}$ & $\begin{array}{c}0.85 \pm 0.18 \\
(0.51-1.29) \\
\end{array}$ & $\begin{array}{l}0.92 \pm 0.11 \\
(0.69-1.23) \\
\end{array}$ & $\begin{array}{l}0.93 \pm 0.11 \\
(0.85-1.10) \\
\end{array}$ & $<0.0001$ \\
\hline LDL-C (mmol/L) & $\begin{array}{l}2.19 \pm 0.93 \\
(1.05-4.35)\end{array}$ & $\begin{array}{l}2.38 \pm 1.11 \\
(0.24-5.30) \\
\end{array}$ & $\begin{array}{l}2.80 \pm 1.01 \\
(0.83-5.70) \\
\end{array}$ & $\begin{array}{l}2.60 \pm 1.19 \\
(0.87-5.00) \\
\end{array}$ & $\begin{array}{l}2.32 \pm 0.66 \\
(1.43-2.93) \\
\end{array}$ & 0.01 \\
\hline $\mathrm{TG}(\mathrm{mmol} / \mathrm{L})$ & $\begin{array}{l}1.52 \pm 0.61 \\
(0.55-3.47)\end{array}$ & $\begin{array}{c}1.92 \pm 0.93 \\
(0.63-4.92)\end{array}$ & $\begin{array}{l}2.04 \pm 0.76 \\
(0.89-3.93)\end{array}$ & $\begin{array}{l}2.22 \pm 1.04 \\
(0.61-5.13)\end{array}$ & $\begin{array}{l}2.41 \pm 0.98 \\
(1.84-3.88)\end{array}$ & 0.003 \\
\hline $\mathrm{AI}(\mathrm{mmol} / \mathrm{L})$ & $\begin{array}{l}4.38 \pm 1.29 \\
(2.03-7.52)\end{array}$ & $\begin{array}{l}4.55 \pm 1.37 \\
(1.96-8.61)\end{array}$ & $\begin{array}{c}4.88 \pm 1.80 \\
(2.58-10.31)\end{array}$ & $\begin{array}{l}4.97 \pm 1.51 \\
(2.87-8.38)\end{array}$ & $\begin{array}{l}4.64 \pm 1.15 \\
(3.65-6.31)\end{array}$ & 0.04 \\
\hline
\end{tabular}

Data are expressed as mean \pm (SD) and (ranges). Analysis of mean difference between groups were performed by ANOVA test.

Table (3) shows that the mean serum TSH level was higher in women than men but there was no statistical significant difference between mean TSH level in person with and without CAD in each sex group. 
Table 3: Gender distribution and mean TSH level in relation to coronary stenosis score.

\begin{tabular}{|c|c|c|c|c|}
\hline \multicolumn{2}{|c|}{ Gender } & $\begin{array}{c}\text { Without } \\
\text { coronary } \\
\text { stenosis }\end{array}$ & $\begin{array}{c}\text { With coronary } \\
\text { stenosis }\end{array}$ & $\begin{array}{c}\text { P- } \\
\text { value }\end{array}$ \\
\hline \multirow{2}{*}{ Male } & $\mathrm{N}$ & 14 & 74 & \multirow{2}{*}{ N.S. } \\
\cline { 2 - 4 } & $\mathrm{TSH}(\mathrm{mIU} / \mathrm{L})$ & $1.31 \pm 0.67$ & $1.68 \pm 0.96$ & \\
\hline \multirow{2}{*}{ Female } & $\mathrm{N}$ & 37 & 25 & \multirow{2}{*}{ N.S. } \\
\cline { 2 - 4 } & $\mathrm{TSH}(\mathrm{mIU} / \mathrm{L})$ & $2.10 \pm 1.26$ & $2.39 \pm 2.17$ & \\
\hline
\end{tabular}

Data are expressed as mean $\pm \mathrm{SD}$.

Evidence suggests that $\mathrm{SCH}$ carried a risk of CAD. Thus, the classification in the present work was done according to TSH level into three groups $(<0.38,0.38-4.31$ and $>4.31 \mathrm{mIU} / \mathrm{L})$. The relationship between TSH and the prevalence of CAD was assessed. Although there is no significant difference of mean TSH across different groups of angiographic score but TSH levels showed a trend toward higher levels in the patients with multivessel disease as in group with score (2, 3 and 4) compared to that with score ( 0 and 1$)$. The extent of CAD and the incidence of multivessel disease increase with the increased of TSH levels ( $\mathrm{p}=0.03)$ (Fig.2).

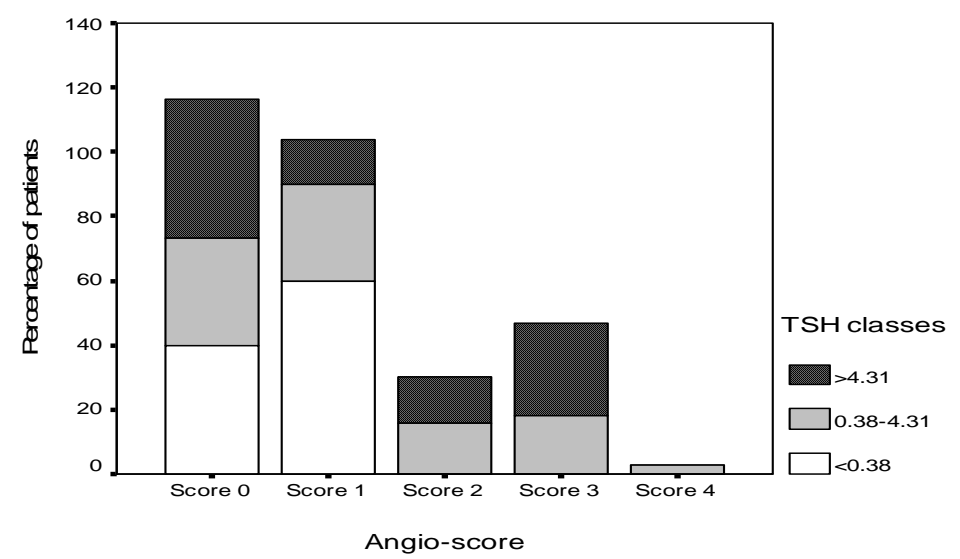

Fig. 2: The relationship between groups of TSH levels and angiography scores.

Table (4) showed patients characteristics according to groups of TSH levels. There was a significant difference regarding gender $(p=0.01)$, BMI $(p=0.05)$ and DM $(p=0.02)$ across different TSH groups. There was an increase in the concentration of TC, LDL-C, TG and $\mathrm{AI}$, and a reduction in HDL-C with the increase TSH level. 
Table 4: Characterstatics of patients according to groups of TSH levels.

\begin{tabular}{|c|c|c|c|c|}
\hline \multirow{2}{*}{\multicolumn{2}{|c|}{ Characteristics }} & \multicolumn{3}{|l|}{ TSH groups } \\
\hline & & $\begin{array}{l}<0.38 \\
N=5\end{array}$ & $\begin{array}{l}0.38-4.31 \\
N=138\end{array}$ & $\begin{array}{l}>4.31 \\
N=7\end{array}$ \\
\hline \multicolumn{2}{|c|}{ Age (Years) } & $\begin{array}{l}53.80 \pm 5.26 \\
(47.00-60.00)\end{array}$ & $\begin{array}{l}53.13 \pm 9.69 \\
(30.00-78.00)\end{array}$ & $\begin{array}{l}55.85 \pm 11.05 \\
(36.00-68.00)\end{array}$ \\
\hline \multirow{2}{*}{ Gender } & Male $(\mathrm{n}) \%$ & (5) $3.3 \%$ & (82) $54.7 \%$ & (1) $0.7 \%$ \\
\hline & Female $(\mathrm{n}) \%$ & $(0)$ & (56) $37.3 \%$ & (6) $4 \%$ \\
\hline \multicolumn{2}{|c|}{ Hypertension (n)\% } & $(2) 1.3 \%$ & (76) $50.7 \%$ & (5) $3.3 \%$ \\
\hline \multicolumn{2}{|c|}{ Diabetes Mellitus (n)\% } & $(3) 2.0 \%$ & (32) $21.3 \%$ & $(4) 2.7 \%$ \\
\hline \multicolumn{2}{|c|}{ Hyperlipidemia (n)\% } & $(1) 0.7 \%$ & $(49) 32.7 \%$ & (3) $2.0 \%$ \\
\hline \multicolumn{2}{|c|}{ Smoker $(\mathrm{n}) \%$} & $(2) 1.3 \%$ & $(40) 26.7 \%$ & (1) $0.7 \%$ \\
\hline \multicolumn{2}{|c|}{ SBP (mm Hg) } & \begin{tabular}{|l|}
$126.00 \pm 25.09980$ \\
$(110.00-170.00)$
\end{tabular} & $\begin{array}{l}133.0435 \pm 20.33 \\
(80.00-185.00) \\
\end{array}$ & $\begin{array}{l}148.57 \pm 20.14 \\
(130.00-180.00)\end{array}$ \\
\hline \multicolumn{2}{|c|}{ DBP (mm Hg) } & $\begin{array}{l}74.00 \pm 5.47 \\
(70.00-80.00)\end{array}$ & $\begin{array}{l}79.74 \pm 14.41 \\
(50.00-185.00)\end{array}$ & $\begin{array}{l}77.85 \pm 6.36 \\
(70.00-85.00)\end{array}$ \\
\hline \multicolumn{2}{|c|}{ BMI $\left(\mathrm{Kg} / \mathrm{m}^{2}\right)$} & $\begin{array}{l}27.9 \pm 27.27 \\
(22.79-39.79) \\
\end{array}$ & $\begin{array}{l}29.73 \pm 5.44 \\
(19.75-55.55) \\
\end{array}$ & $\begin{array}{l}34.57 \pm 6.24 \\
(24.97-42.96) \\
\end{array}$ \\
\hline \multicolumn{2}{|c|}{ FT4 (ng/dl) } & $\begin{array}{l}1.61 \pm 0.16 \\
(1.38-1.76)\end{array}$ & $\begin{array}{l}1.42 \pm 0.28 \\
(0.80-2.17)\end{array}$ & $\begin{array}{l}1.32 \pm 0.54 \\
(0.69-1.93)\end{array}$ \\
\hline \multicolumn{2}{|c|}{$\mathrm{TC}(\mathrm{mmol} / \mathrm{L})$} & $\begin{array}{l}4.05 \pm 1.10 \\
(2.27-5.29)\end{array}$ & $\begin{array}{l}4.3 \pm 41.18 \\
(1.84-8.06)\end{array}$ & $\begin{array}{l}4.93 \pm 1.32 \\
(3.22-7.04)\end{array}$ \\
\hline \multicolumn{2}{|c|}{$\mathrm{HDL}-\mathrm{C}(\mathrm{mmol} / \mathrm{L})$} & $\begin{array}{l}0.98 \pm 0.09 \\
(0.82-1.07)\end{array}$ & $\begin{array}{l}0.94 \pm 0.25 \\
(0.9657-.9500)\end{array}$ & $\begin{array}{l}0.91 \pm 0.29 \\
(0.56-1.33)\end{array}$ \\
\hline \multicolumn{2}{|c|}{ LDL-C (mmol/L) } & $\begin{array}{l}2.49 \pm 1.07 \\
(0.88-3.87)\end{array}$ & $\begin{array}{l}2.51 \pm 1.08 \\
(0.24-5.70)\end{array}$ & $\begin{array}{l}2.91 \pm 0.76 \\
(1.92-4.00)\end{array}$ \\
\hline \multicolumn{2}{|c|}{$\mathrm{TG}(\mathrm{mmol} / \mathrm{L})$} & $\begin{array}{l}1.17 \pm 0.32 \\
(0.73-1.64)\end{array}$ & $\begin{array}{l}1.88 \pm 0.87 \\
(0.55-5.13)\end{array}$ & $\begin{array}{l}2.26 \pm 0.78 \\
(1.38-3.84)\end{array}$ \\
\hline \multicolumn{2}{|c|}{$\mathrm{AI}(\mathrm{mmol} / \mathrm{L})$} & $\begin{array}{l}4.31 \pm 1.10 \\
(2.76-5.81)\end{array}$ & $\begin{array}{l}4.61 \pm 1.48 \\
(1.96-10.31)\end{array}$ & $\begin{array}{l}5.020 .60 \\
(4.17-5.75)\end{array}$ \\
\hline
\end{tabular}




\section{DISCUSSION}

This study showed that variation of TSH within normal range might influence the extent and the severity of CAD but not the presence of CAD. Thus, the higher levels of TSH were associated with multivessel disease $(\mathrm{p}=0.03)$.

Accordingly, the results of this work are in agreement with those obtained by other

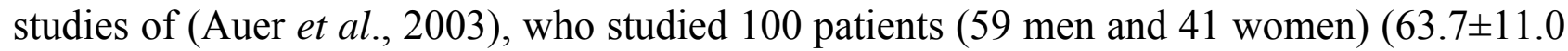
years), whom underwent coronary angiography. They concluded that higher TSH concentrations were associated with increasing severity of coronary atherosclerosis $(\mathrm{p}=0.049)$.

Yun et al., (2005), studied 125 patients (84 males and 41females) their age (60 111.1$)$ years whom underwent diagnostic coronary angiography, they found that TSH was significantly higher $(\mathrm{p}=0.053)$ in patients with multivessel diseases compared to those with normal coronary arteries.

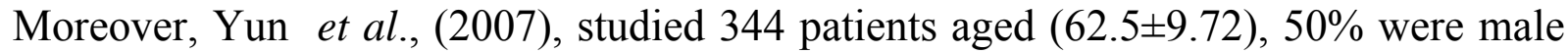
who underwent elective coronary angiography. The incidence of multivessel disease was statistically higher $(\mathrm{p}=0.03)$ in patients with high TSH.

In the present study, there was no association between TSH level and the presence of CAD. Although the mean TSH was higher in women than men, but there was no statistical significant difference between mean TSH levels in person with and without CAD in each sex group.

This result was similar to that of (Shams et al., 2005) whom performed a cross sectional study on 390 patients (239 males and 151 females) with mean age of $(55.12 \pm 10.52)$ years who had referred to the unit of coronary angiography. They reported that mean serum TSH was significantly higher in women. Moreover, there was no correlation $(\mathrm{p}=0.37)$ between TSH level and the presence of CAD in either sex.

Thyroid hormones regulate the expression of enzymes involved in all steps of lipid metabolism leading to the development of qualitative and quantative changes of lipids. (Zhu et al., 2010). Dyslipidemia coexist with other metabolic abnormalities, including hypertension, insulin resistance and oxidative stress, all of them being risk factor for CVD. (Peppa et al., 2011).

It was reported that thyroid function tests were altered in patients with a cute coronary syndrome (ACS). These changes are characterized by euthyroid sick syndrome. However, thyroid functions were not associated with the widespread of coronary artery disease according to coronary angiography $(\mathrm{P}>0.05)$. (Tuzun et al., 2010).

The abnormality of thyroid hormones that lead to CAD through different mechanisms including effects on endothelial functions, relaxation of smooth muscles and blood rheology. (Fazio et al., 2004).

In notice, regarding our study results, most of the major risk factors had a clear significance as a predictors for developing (CAD patient's age $p=0.007$, male $p=0.001$, hypertension $\mathrm{p}=0.05$, DM $\mathrm{p}=0.02$, hyperlipidemia $\mathrm{p}=0.05$, smoking $\mathrm{p}=0.001$ and BMI $\mathrm{p}=0.05)$, this is in accordance with the common medical knowledge.(Kaspar et al., 2005).

Risk for CAD increases steeply with advancing age in both sex. The principal reason is that age is a reflection of the progressive accumulation of coronary atherosclerosis. (Wilson et al., 1998). Also, at any age male are at a greater risk of CAD than female, this 
can be explained by earlier onset of risk factor in male such as elevation of LDL-C, blood pressure and reduction of HDL-C. (Mendelson and Karas, 1999)

Hypertension is a major independent risk factor for CAD, it may induce endothelial injury to the walls of coronary arteries, it also increases the workload on the heart (Padwal et al., 2001). People with DM are at a greater risk of CAD, High blood glucose levels over time can lead to increase the deposits of fatty materials on the insides of the blood vessel walls. These deposits may affect blood flow, increasing the chance of clogging and hardening of blood vessels (Herlitz et al., 1992).

There is a positive association between the increased BMI and the risk of CAD. The increased BMI is associated with an adverse effect on all major CAD risk factors including dyslipidemia, DM and hypertension (Fava et al., 1996). The relationship of smoking to CAD is dose dependent and observed in men and women (Campisi et al., 1998).

From this study, it was observed that the extent of CAD that is represented by the angiography score is positively associated with the atherogenic lipids (TC, LDL-C, TG) and negatively associated with antiatherogenic HDL-C. This agrees with the study perfomed by (Tarchalski et al., 2003).

The synthesis of TSH might be affected by the mass of adipose tissue. It was found that there were receptors expressed for TSH in adipose tissue (Kershaw and Flier, 2004). In the present work, it was observed that there is a significant increase in BMI with the elevation of TSH level. This observation was in accordance with (Nyrnes et al., 2006) which found a positive association between TSH within normal range and BMI.

The current study shows that TSH level significantly increased in patients with DM $(p=0.02)$ and this is comparable to one study (Chubb et al., 2005). The research demonstrated that at a low insulin sensitivity, relatively minor differences in TSH are associated with the marked change in lipid levels that is a risk factor for CVD.

The observation drawn from this study regarding serum TC, LDL-C and TG increased with increasing TSH level, while HDL-C decreased. These results were comparable to those obtained by other researchers (Asvold et al., 2007; Patidar et al., 2012). They reported that mild elevation of TSH is associated with changes in lipid profile that significantly raised the risk of cardiovascular disorders.

The pathophysiological process behind the abnormality of thyroid functions on lipid metabolism including: 1- High serum TC and LDL-C might be caused by fewer cell-surface receptors for LDL, resulting in reduced LDL catabolism (Cappola and Ladenson, 2003). 2High serum TG might be caused by reduced activity of lipoproteins lipase (Lithell et al., 1981) or impaired clearance of lipoproteins dependant on LDL receptor function (Liu et al., 1998) might result in higher levels.

\section{CONCLUSION}

This cross sectional study suggested that the high level of serum TSH is associated with multi-vessel disease, but it was not the determinant of CAD in patients with the normal range of thyroid functions.

The positive association between the TSH in reference range and concentration of serum TC, LDL-C and TG, and a negative association of TSH and HDL-C was found.

Although clinically and biochemically levels of TSH indicate normal thyroid functions but it might have long term harmful effects on cardiovascular health by the association with the abnormal serum lipids. 


\section{REFERENCES}

Asvold, B.O.; Vatten, L.J.; Nilsen, T.I.L.; Bjoro, T. (2007). The association between TSH within the reference range and serum lipid concentrations in a population-based study. Euro. J. Endocr., 156, 181-186.

Auer, J.; Berent, R.; Weber, T.; Lassing, E.; Eber, B. (2003). Thyroid function is associated with presence and severity of coronary atherosclerosis. Clin. Cardiol., 26, 569573.

Bakker, S. J.; Maaten, J.C.; Popp-Snijders, C.; Slaets, J.P.; Heine, R.J.; Gans, R.O. (2001). The relationship between thyrotropin and low density lipoproteine cholesterol is modified by insulin sensitivity in healthy euthyroid subjects. J. Clin. Endocrinl. Metab., 86, 1206-1211.

Becker, C. (1985). Hypothyroidism and atherosclerotic heart disease: pathogenesis, medical management, and the role of coronary artery bypass surgery. Endocr. Rev., 6, 432440.

Bishop, M.; Fody, F.; Schoeff, L. (2005). "Clinical Chemistry". 5th ed., procedures, Principles and Correlation. Lippincott Williams . New York, USA, pp.302-303.

Burtis, C.A.; Ashwood, E.R.; Bruns, D.E. (2006). "Tietz Textbook of Clinical Chemistry and Molecular Diagnostics". 4th ed., Lipids, Lipoproteins, Apolipoproteins, and Other Cardiovascular Risk Factors. Elsevier Saunders. Philadephia, USA. pp. 948.

Campisi, R.; Czernin, J.; Schoder, H.; Sayre, J.W.; Marengo, F.D.; Phelps, M. E. (1998). Effects of long -term smoking on myocardial blood flow, coronary vasomotion and vasodilator capacity. Circulation., 98, 119-125.

Cappola, A. R.; Ladenson, P. W. (2003). Hypothyroidism and atherosclerosis. J. Clin. Endocrinol. Metab., 88, 2438-2444.

Chan, D.C.; Watts, G.F.; Barrett, P.H.; Burke, V.S. (2003). Waist circumference, waist-tohip ratio and body mass index as predictors of adipose tissue compartments in men. QJ Med., 96, 441-447.

Chubb, S.A.P.; Davis, W.A.; Davis, T.M.E.(2005). Interaction among thyroid function, insulin sensitivity and serum lipid concentrations: the fremantle diabetes study. $J$. Clin Endocrinol Metab., 90, 5317-5320.

Fazio, S.; Palmieri, E.A.; Lombardi, G.; Biondi, B. (2004). Effects of thyroid hormone on the cardiovascular system. Recent Prog. Horm. Res., 59, 31-50.

Friedewald, W.T.; Levy, R. I.; Fredrickson, D. S. (1972). Estimation of the concentration of LDL-C in plasma without use of preparative ultra centrifuge. Clin. Chem., 18,499502.

Herlitz, J.; Karlson, B.W.; Edravdsson, N.; Emanuelsson, H.; Hjalmarson, A. (1992). Prognosis in diabetics with chest pain or other symptoms suggestive of acute myocardial infarction. Cardiology., 80, 237-245.

Judkin, M.F.(1976). Selective coronary arterography: A percutaneous transfemoral technique. Radiology., 89, 815-824.

Kasper, D. L.; Braunwald, E.; Fauci, A. S. ( 2005). Harrison's Principles of Internal Medicine.16th ed. McGraw-Hill pub. United States.

Kershaw, E. E.; Flier, J.S. (2004). Adipose tissue as an endocrine organ. J. Clin. Endocrinol. Metab., 89, 2548-2556. 
Lamon, F.S.; Wilson, P.W.F.; Schaefer, E.J. (1996). Impact of body mass index on coronary heart disease risk factors in men and women. AHA., 16, 1509-1515.

Lithell, H.; Boberg, J.; Hellsing, K.; Ljunghall, S.; Lundqvist, G.; Vessby, B.; Wide, L. (1981). Serum lipoprotein and apolipoprotein concentrations and tissue lipoproteinlipase activity in overt and subclinical hypothyroidism: the effects of substitution therapy. Europ J. Clin. Invest., 11, 3-10.

Liu, X.; Rahman, A.; Bagdade, J.D.; Alaupovic, P.; Kannan, C.R. (1998). Effects of thyroid hormone on plasma apolipoproteins and apoA-and apoB-containing lipoprotein particles. Europ J. Clin. Invest., 28, 266-270.

Mendelsohn, M.E.; Karas, R.H. (1999). The protective effects of estrogen on the cardiovascular system. N. Engl. J. Med., 340, 1801-1811.

Miura, S.; Litaka, M.; Suzuki, S.; Fukasawa, N.; Kitahama, S.; Kawakami, Y. (1996). Decreased in serum levels of thyroid hormone in patients with coronary heart disease. Endocr. J., 43,657-663.

Nyrnes, A.; Jorde, R.; Sundfjord, J. (2006). Serum TSH is positively associated with BMI. IJO., 30,100-105.

Padwal, R.; Straus, S.H.; McAlister, F. (2001). Cardiovascular risk factors and their effects on the decision to treat hypertension: evidence based review . BMJ., 322, 977-980.

Patidar, R.K.; Raghuwanshi, R.; Sharma, P.; Singh, V. (2012). An associative investigation between TSH and serum lipid concentrations in the population of Bhopal, India. IJPSR., 3 (4),1112-1115.

Peppa, M.; Betsi, G.; Dimitriadis, G. (2011). Lipid abnormalities and cardiometabolic risk in patients with overt and subclinical thyroid disease. J. Lipids., 2011, 1-9.

Ringqvist, I.; Fisher, L.D.; Mock, M.; Davis, K.B.; Wedel, H.; Chaitman, B.R.; Passamani, E.; J.R. Russell, R.O.; Alderman, E. L.; Kouchoukas, N.T.; Kaiser, G.C.; Ryan, T.J.; Killip, T.; Fray, D. (1983). Prognostic value of angiographic indices of coronary artery disease from the coronary artery surgery study. J. Clin. Invest., 71, 1854-1866.

Shams, M.; Sharif-Kazemi, M.B.; Lankarani, K.B.; Sadegholvad, A.S.; Omrani, G.R. (2005). Are serum thyrotropine level and subclinical hypothyroidism predisposing factors for coronary artery disease? Int. J. Endocrinol. Metab., 2, 67-73.

Surks, M. I.; Ortiz, E.; Daniels, G.H.; Swain, C.T.; Col, N.F.; Cobin R.H.; Franklen, J.A.; Hershman, J.M.; Burman, K.D.; Denke, M.A.; Gorman, C.; Cooper, RS.; Weissman, NJ. (2004). Subclinical Thyroid disease: scientific review and guidelines for diagnosis and management. JAMA., 291(2), 228-238.

Tarchliski, J.; Guzik, P.; Wysocki, H.(2003). Correlation between the extent of coronary atherosclerosis and lipid profile. Mol Cell Biochem., 246, 25-30.

Tieche, M.; Lupi, G.A.; Gutzwiller, F.; Grop, P.J.; Studer, H.; Burgi, H. (1981). Borderline low thyroid function and thyroid autoimmunity. Risk factor for coronary heart disease? Br Heart J.,46, 202-206.

Tuzun, D.; Bayram, N.A.; Cicek, O.F.; Ersoy, R.; BozKurt, E.; Cakir, B. (2010). Are thyroid functions associated with widespread of acute coronary syndromes? Endocrin Abst., 22, p133. 
Wilson, P.F.; Agostino, R.B.; Levy, D.; Belanger, A.M.; Silbershatz, H.; Kannel, W.B. (1998). Prediction of coronary heart disease using risk factor. Circulation., 97, $1837-1847$.

Yun, K.H.; Jeong, M.H.; Kang, D.G.; Kim, K.H.; Lim, S.Y.; Lee, Y.S.; Lee, S.H.; Hong, S.N.; Hong, Y.J.; Kim, J.H.; Ahn, Y.K.; Cho, J.G.; Park, J.C.; Kim, N.H.; Oh, S.K.; Jeong, J.W.; Kang, J.C. (2005). Is thyroid hormone a risk factor of coronary atherosclerosis in Korean patients? Korean J. Circ., 35 (1), 43-48.

Yun, K.H.; Jeong, M.H.; Oh, S.K.; Lee, E.M.; Lee, J.; Rhee, S.J.; Yoo, N.J.; Kim, N.H.; Ahn, Y.K.; Jeong, J.W. (2007). Relationship of thyroid stimulating hormone with coronary atherosclerosis in angina patients. Int. J. Cardiol., 122 (1), 56-60.

Zhu, X.; Cheng, S.Y. (2010). New insights into regulation of lipid metabolism by thyroid hormone. Curr. Opin. Endocrinol. Diabetes Obes., 17 (5), 408-413. 